\title{
Glosa do wyroku ETPC w sprawie Diacenco przeciwko Rumunii z 7 lutego 2012 roku, skarga nr 1245/04
}

DOI: http://dx.doi.org/10.12775/SIT.2014.019

Glosowany wyrok dotyka zagadnienia domniemania niewinności, ukazując jego wielowymiarowość. Domniemanie niewinności ma bowiem szereg aspektów, a jego zasięg nie jest ograniczony do ram postępowania karnego.

Orzeczenie w sprawie Diacenco zostało wydane w kontekście relacji pomiędzy odpowiedzialnością karną a cywilną wynikającą $z$ tego samego czynu, mogącego stanowić jednocześnie przestępstwo i czyn niedozwolony. W sprawie tej skarżący został uniewinniony w I instancji od zarzutu spowodowania wypadku komunikacyjnego. W związku $\mathrm{z}$ wyrokiem uniewinniającym oddalono też powództwo cywilne jednego $z$ pokrzywdzonych. Wyrok ten został utrzymany w mocy przez sąd I instancji. Natomiast sąd apelacyjny, utrzymując w mocy wcześniejsze wyroki uniewinniające, zasądził od oskarżonego kwotę dochodzoną powództwem adhezyjnym, kwestionując ustalenia faktyczne sądów niższych i wskazując w uzasadnieniu, że uważa oskarżonego za winnego spowodowania wypadku, a fakt uniewinnienia od popełnienia przestępstwa nie ma znaczenia z punktu widzenia odpowiedzialności cywilnej.

Na początek warto przyjrzeć się kwestii dopuszczalności skargi. Trybunał nie podzielił zastrzeżeń rządu rumuńskiego, że skarżący nie odniósł znaczącego uszczerbku w rozumieniu art. 35 
ust. 3 pkt b. Ze stanowiskiem Trybunału należy się zgodzić. Jeśli w tego rodzaju sprawie za kryterium oceny uznać przede wszystkim wpływ rozstrzygnięcia na sytuację finansową skarżącego, to należy zauważyć, że skarżącemu nakazano zapłatę równowartości ok. 1800 euro osobiście i ok. 800 euro solidarnie $z$ zakładem ubezpieczeń, w sytuacji, gdy jego zarobki wynosiły równowartość ok. 220 euro. Zasądzona suma stanowiła zatem wielokrotność miesięcznych zarobków. Poza tym nie mniej ważny jest aspekt niefinansowy. Zdaniem skarżącego nie ponosił on winy za zdarzenie, gdyż brak oświetlenia pojazdu, w który uderzył, uniemożliwił mu uniknięcie wypadku. Stwierdzenie jego odpowiedzialności cywilnej za czyn mogło bez wątpienia naruszać dobre imię i gwarancje wynikające $z$ wcześniejszego prawomocnego uniewinnienia.

Przechodząc do meritum skargi, trzeba zauważyć, że domniemanie niewinności oskarżonego nie zostało naruszone w głównym nurcie procesu karnego. Został on prawomocnie uniewinniony od zarzutu popełnienia czynu. Pozwany cywilnie nie jest zaś co do zasady „oskarżonym o popełnienie czynu zagrożonego karą” w rozumieniu art. 6 ust. 2 EKPC. W cywilnym nurcie niniejszej sprawy nie zostały spełnione trzy kryteria brane pod uwagę przez ETPC przy ocenie posiadania wymienionego statusu: klasyfikacja postępowania na gruncie prawa krajowego, jego natura oraz surowość kary grożącej oskarżonemu. Prawo krajowe czyniło wyraźną różnicę pomiędzy postępowaniem karnym a cywilnym, w tym pierwszym zaś oskarżony został uniewinniony. Natura postępowania adhezyjnego była zaś stricte cywilna i powiązana $z$ odpowiedzialnością deliktową za czyn zabroniony. Co wypada zauważyć, w prawie rumuńskim rozstrzygnięcie w przedmiocie odpowiedzialności karnej od strony formalnej nie wpływało na rozstrzygnięcie w przedmiocie odpowiedzialności cywilnej, tj. zasądzenie odszkodowania było możliwe zarówno przy wyroku skazującym, jak i uniewinniającym. Roszczenie cywilne miało przy tym charakter wyłącznie odszkodowawczy, tj. powód cywilny nie dochodził kwoty wyższej niż wysokość szkody. Sam zaś fakt, że dany czyn mógł być równocześnie traktowany jako czyn zabroniony i delikt cywilny, a dowody zgromadzone w celu rozstrzygnięcia w przedmiocie odpowiedzialności karnej wykorzystane równocześnie w procesie cywilnym, nie może powodować tego, aby 
pozwanego potraktować w kategoriach oskarżonego, a odpowiedzialność deliktową jako rodzaj odpowiedzialności karnej.

Na podkreślenie zasługuje zatem teza ETPC, że choć „uniewinnienie od odpowiedzialności karnej powinno być respektowane w postępowaniu odszkodowawczym, nie powinno ono wykluczać ustalenia odpowiedzialności cywilnej w zakresie zapłaty odszkodowania, wynikającej $z$ tych samych faktów na podstawie mniejszych wymagań co do standardu udowodnienia. Jednakże jeśli krajowa decyzja w przedmiocie odszkodowania zawiera stwierdzenia przypisujące odpowiedzialność karną pozwanemu, może to generować zagadnienie wchodzące w zakres art. 6 ust. 2 Konwencji”. Podobne stanowisko zajął Trybunał już wcześniej m.in. w sprawie Ringvold ${ }^{1}$.

Analiza stwierdzenia sądu apelacyjnego zawarta w uzasadnieniu wyroku w niniejszej sprawie nie pozostawia wątpliwości, że domniemanie niewinności zostało naruszone. Pomimo utrzymania w mocy wyroku uniewinniającego, w uzasadnieniu sąd wprost uznał oskarżonego za sprawcę zarzucanego mu czynu, de facto podważając tym samym wcześniejszy wyrok w sprawie ${ }^{2}$. Nie ma tutaj znaczenia, że stwierdzenia takie miały miejsce w części motywacyjnej, a nie dyspozytywnej orzeczenia. Część motywacyjna jest bowiem także ważna $z$ punktu widzenia odbioru społecznego i odbioru orzeczenia przez uczestników postępowania.

Odnosząc powyższe uwagi do polskich realiów, należy z zadowoleniem skonstatować, że w naszym procesie karnym opisana sytuacja nie mogłaby zaistnieć, ponieważ k.p.k. pozwala na uwzględnienie powództwa adhezyjnego jedynie w razie skazania oskarżonego (art. $415 \S 1$ k.p.k.). Tym samym w ramach postępowania karnego niemożliwe jest wydanie wyroku uniewinniającego $\mathrm{z}$ równoczesnym uwzględnieniem powództwa cywilnego.

Nie oznacza to wszakże, że glosowane orzeczenie nie ma znaczenia z punktu widzenia polskiej praktyki. Wydanie wyroku uniewin-

${ }^{1}$ Wyrok ETPC z 11 lutego 2003 roku w sprawie Ringvold przeciwko Norwegii, skarga nr 34964/97, § 38.

2 Por. S. Trechsel, Human Rights in Criminal Proceedings, Oxford 2006, s. $182-185$. 
niającego nie stoi bowiem na przeszkodzie dochodzeniu roszczeń odszkodowawczych wynikających z tego samego czynu przed sądem cywilnym. Sąd cywilny nie jest wszak związany wyrokiem uniewinniającym (czy też umarzającym postępowanie) wydanym przez sąd karny (art. 11 k.p.c. a contrario). Zasądzając roszczenie $z$ czynu niedozwolonego, który był wcześniej przedmiotem analizy sądu karnego jako przestępstwo i gdzie wydano wyrok uniewinniający czy umarzający, sąd cywilny musi jednak zwracać uwagę na stwierdzenia formułowane przy uzasadnianiu orzeczenia. Nie mogą one poddawać w wątpliwość prawomocnego wyroku uwalniającego oskarżonego od odpowiedzialności karnej. Ponieważ przesłanki odpowiedzialności cywilnej różnią się od przesłanek odpowiedzialności karnej, odpowiednie uzasadnienie wyroku nie powinno sprawiać większych trudności. Sąd cywilny nie powinien formułować stanowiska odnośnie do odpowiedzialności karnej odmiennego od stanowiska sądu karnego. Nie ogranicza to wyłączenia zasady swobodnej oceny dowodów, gdyż możliwa jest odmienna od sądu karnego ocena zarówno poszczególnych dowodów przeprowadzonych w obu postępowaniach, jak i też całokształtu materiału dowodowego, pod warunkiem, że będzie odnosić się do deliktu cywilnego, a nie przestępstwa.

Potwierdzeniem tego punktu widzenia jest orzeczenie ETPC w sprawie Allen ${ }^{3}$, gdzie podkreślono, że jednym $z$ aspektów zasady domniemania niewinności jest zapewnienie, aby po prawomocnym uniewinnieniu lub umorzeniu postępowania osoby publiczne i władze nie traktowały osoby, przeciwko której toczyło się postępowanie, jako winnej. Wymagane jest zatem poszanowanie dla orzeczeń uniewinniających i umarzających postępowanie, w przeciwnym razie domniemanie niewinności stałoby się gwarancją jedynie teoretyczną i iluzoryczną. W tym zakresie - zdaniem ETPC - ochrona przewidziana w art. 6 ust. 2 może pokrywać się częściowo $z$ ochroną gwarantowaną w art. 8 EKPC.

W kontekście tych rozważań wątpliwości musi wzbudzać stanowisko SN wyrażone w wyroku z 18 grudnia 2008 roku $^{4}$, że „W sytu-

${ }^{3}$ Wyrok ETPC z 12 lipca 2013 roku w sprawie Allen przeciwko Zjednoczonemu Królestwu, skarga nr 25424/09, § 94.

${ }^{4}$ III CSK 193/08, LEX nr 487538. 
acji, w której w postępowaniu karnym nie stwierdzono popełnienia przestępstwa, sąd cywilny jest uprawniony do dokonania własnej oceny, czy popełnione zostało przestępstwo. Stwierdzenie przez sąd cywilny, że popełnione zostało przestępstwo, wymaga dokonania własnych ustaleń dotyczących istnienia podmiotowych i przedmiotowych znamion przestępstwa, według zasad przewidzianych w prawie karnym”. Kategoryczność tego poglądu prowadzi do wniosku, że w każdym przypadku uniewinnienia czy umorzenia postępowania karnego, sąd cywilny mógłby dokonać odmiennych ustaleń. Ten pogląd SN, zaaprobowany w późniejszych orzeczeniach ${ }^{5}$, należy poddać krytyce. Jego aprobata prowadziłaby do wniosku, że rozstrzygnięcie w przedmiocie odpowiedzialności karnej mogłoby zapaść orzeczeniem innego sądu niż karny. Doszłoby tutaj do swoistego pomieszania jurysdykcji sądów cywilnych i karnych. Ta linia orzecznictwa SN pozostaje zatem w sprzeczności w punktem widzenia ETPC wyrażonym $\mathrm{w}$ glosowanym orzeczeniu.

Wątpliwości nasuwają także przepisy prawa cywilnego materialnego odwołujące się do pojęcia przestępstwa, zbrodni czy występku, jak chociażby art. $442^{1} \S 2$ k.c., zgodnie $z$ którym jeżeli szkoda wynikła ze zbrodni lub występku, roszczenie o naprawienie szkody ulega przedawnieniu $z$ upływem lat 20 od dnia popełnienia przestępstwa bez względu na to, kiedy poszkodowany dowiedział się o szkodzie i o osobie obowiązanej do jej naprawienia. Zastosowanie tego przepisu nie budzi zastrzeżeń w sytuacji stwierdzenia winy przez sąd karny, co jednak jeśli mamy do czynienia z orzeczeniem, które nie przełamuje domniemania niewinności? W doktrynie prawa cywilnego przyjmuje się, ${ }^{6}$ że sąd cywilny może samodzielnie dokonywać ustaleń co do przestępnego charakteru czynu, choć nie musi to być związane $z$ imiennym wskazaniem sprawcy. Jak jednak należy przypuszczać, w większości przypadków trudno byłoby wypowiadać się co do przestępności czynu bez odniesienia się do jego sprawcy. Oznaczałoby to w konsekwencji przypisanie sprawstwa określonej

${ }^{5}$ Zob. wyrok Sądu Apelacyjnego w Warszawie z 3 listopada 2011 roku, VI ACa 1249/11, LEX nr 1124822.

${ }^{6}$ Zob. np. Komentarz do kodeksu cywilnego. Księga trzecia. Zobowiązania, red. G. Bieniek, t. 1, Warszawa 2002, s. 417. 
osobie, także bez orzeczenia sądu karnego lub też wbrew takiemu orzeczeniu, jeżeli ma ono charakter inny niż wyrok stwierdzający winę (skazujący, warunkowo umarzający postępowanie).

Stanowisko zajęte przez Trybunał może zatem wymusić zmianę linii orzeczniczej sądów cywilnych w zakresie możliwości czynienia ustaleń odmiennych od poczynionych wcześniej w postępowaniu karnym. Do rozważenia jest także rezygnacja $z$ odwoływania się przez prawo cywilne do pojęcia przestępstwa, zbrodni czy występku, co zwalniałoby sąd cywilny od wypowiadania się co zaistnienia tych czynów.

Po stwierdzeniu naruszenia domniemania niewinności Trybunał uznał, że nie zachodzi potrzeba analizy sprawy pod kątem naruszenia art. 6 i 7 EKPC. To rozstrzygnięcie należy poddać krytyce. Jeśli chodzi o art. 7, to jak należy się spodziewać, Trybunał nie stwierdziłby naruszenia. Przepis ten zakazuje podwójnego karania za ten sam czyn. Mając na względzie wspomniany fakt, że roszczenia nie przewyższały wysokości wyrządzonej szkody, a odpowiedzialność karna ma inny charakter od cywilnej, trudno mówić tu o powtórnym karaniu. Natomiast nie ma podstaw, aby Trybunał nie wypowiedział się w przedmiocie naruszenia prawa do rzetelnego procesu ze względu na przeprowadzenie postępowania pod nieobecność strony. Naruszenie takie mogłoby skutkować bowiem koniecznością powtórzenia postępowania, w sytuacji, kiedy dla usunięcia naruszenia art. 6 ust. 2 wystarczająca byłaby zmiana uzasadnienia wyroku. Naruszenie prawa do rzetelnego procesu pociąga zatem za sobą dalej idące skutki.

Na zakończenie kilka słów warto poświęcić kwestii odszkodowania za naruszenie domniemania niewinności. Trybunał nie stwierdził w sprawie szkody majątkowej, z czym można się zgodzić, natomiast w zakresie szkody niemajątkowej przyznał 2000 euro tytułem zadośćuczynienia za szkodę wynikłą $z$ naruszenia domniemania niewinności. Zauważyć zatem należy, że nie uznano stwierdzenia naruszenia za wystarczającą rekompensatę, co zasługuje na aprobatę. Naruszenie domniemania niewinności może bowiem rodzić dla poszkodowanego dotkliwe skutki, uzasadniające przyznanie odpowiedniego zadośćuczynienia. 